Institute of $\mathbf{F}_{\text {ood and }} \mathbf{A}_{\text {gricultural }} \mathbf{S}_{\text {ciences }}$

\title{
2003 Handbook of Employment Regulations Affecting Florida Farm Employers and Workers: Occupational Safety and Health Act (OSHA) Hazard Communication Standard [Federal] ${ }^{1}$
}

Leo C. Polopolus, Michael T. Olexa, Fritz Roka, and Carol Fountain ${ }^{2}$

\section{Purpose}

To require certain employers to inform their employees of the dangers of hazardous chemicals.

\section{Who Must Comply}

- Employers who manufacture, import, distribute, store, or use hazardous chemicals in the workplace must inform employees of these hazards by means of a written Hazard Communication Program.

- Agricultural employers with eleven or more employees (full-time or part-time) at any one time during the previous twelve months are subject to enforcement of OSHA's Hazard

Communication (or Right-to-Know) Standard.

Note: The Environmental Protection Agency, not OSHA, regulates the application of pesticides. (See EDIS document FE422, Worker Protection Standard-EPA [Federal] for pesticide safety requirements.)

\section{Hazard Communication Program}

The Hazard Communication Standard requires employers to develop and implement a written Hazard Communication Program for their workplace. The program must specify how the requirements for

1. This is EDIS document FE409, a publication of the Department of Food and Resource Economics, Florida Cooperative Extension Service, Institute of Food and Agricultural Sciences, University of Florida, Gainesville, FL. Published July 2003. This information is included in Circular 1200, Handbook of Employment Regulations Affecting Florida Farm Employers and Workers. First published February 1992 as Circular 1043 . Revised December 2002 as Circular 1200. Please visit the EDIS website at http://edis.ifas.ufl.edu.

2. Leo C. Polopolus, Professor Emeritus, Department of Food and Resource Economics, University of Florida, Gainesville, FL; Michael T. Olexa, Professor, Department of Food and Resource Economics, University of Florida, Gainesville, FL; Fritz Roka, Associate Professor, Department of Food and Resource Economics, Southwest Florida Research and Education Center, Immokalee, FL; and Carol Fountain, Assistant Editor, Department of Food and Resource Economics, University of Florida, Gainesville, FL; Florida Cooperative Extension Service, Institute of Food and Agricultural Sciences, University of Florida, Gainesville, FL.

This document is designed to provide accurate, current, and authoritative information on the subject. However, since the laws, administrative rulings, and court decisions on which it is based are subject to constant revision, portions of this publication could become outdated at any time. This publication is distributed with the understanding that the authors are not engaged in rendering legal or other professional advice, and the information contained herein should not be regarded as a substitute for professional advice. For these reasons, the utilization of these materials by any person constitutes an agreement to hold harmless the authors, the Institute of Food and Agricultural Sciences, and the University of Florida for any liability claims, damages, or expenses that may be incurred by any person as a result of reference to or reliance on the information contained in this publication.

The Institute of Food and Agricultural Sciences is an equal opportunity/affirmative action employer authorized to provide research, educational information and other services only to individuals and institutions that function without regard to race, color, sex, age, handicap, or national origin. For information on obtaining other extension publications, contact your county Cooperative Extension Service office. Florida Cooperative Extension Service/Institute of Food and Agricultural Sciences/University of Florida/Christine Taylor Waddill, Dean. 
labeling and other forms of warning, material safety data sheets (MSDSs) and employee information and training will be met. It must also include:

- A list of the hazardous chemicals present in the workplace (on agricultural/horticultural operations, these might include such chemicals as kerosene or propane).

- The methods the employer will use to inform employees of the hazards of nonroutine tasks involving hazardous chemicals.

- The methods the employer will use to inform contractor employers of the hazards their employees may be exposed to in the workplace.

The written Hazard Communication Program must be made available, upon request, to employees, their representatives, OSHA officials, and U.S. Department of Health and Human Services officials.

\section{Labels}

Chemical manufacturers, importers, and distributors shall ensure that each container of hazardous chemicals leaving the workplace is labeled, tagged, or marked with the following information:

- Identity of the hazardous chemical(s).

- Appropriate hazard warnings.

- Name and address of the chemical manufacturer, importer, or other responsible party.

The employer is not required to label portable containers into which hazardous chemicals are transferred from labeled containers intended for the immediate use of the employee who performs the transfer.

The employer shall ensure that labels or other forms of warning are legible, in English, and prominently displayed. Employers employing non-English speaking workers may label this material in the worker's language as long as it is also labeled in English.
Employers are not required to label pesticides that are subject to the labeling requirements of the Federal Insecticide, Fungicide, and Rodenticide Act.

\section{Material Safety Data Sheets (MSDS)}

A Material Safety Data Sheet (MSDS) is a document, written in English, containing standardized information about the properties and hazards of toxic substances. Manufacturers and importers of toxic chemicals are required to prepare, update, and furnish MSDSs to their distributors and employers.

If an MSDS is not furnished with a shipment labeled as hazardous chemicals, the purchaser (employer) shall obtain an MSDS from the chemical manufacturer, importer, or distributor.

Employers shall have on file an MSDS for each hazardous substance in the workplace and ensure they are readily accessible during each work shift to employees when they are in the work area(s).

MSDSs shall also be readily available, upon request, to official representatives of the U.S. Department of Labor (OSHA) and the U.S. Department of Health and Human Services.

\section{Information and Training}

Employers shall provide employees with information and training on hazardous chemicals in the work area at the time of their initial assignment and whenever a new hazard is introduced into their work area.

- Information. Employees shall be informed of the following:

- Information and training requirements of the law.

- Any operations in work area where hazardous chemicals are present.

- The location and availability of the written Hazard Communication Program, including the required list(s) of hazardous chemicals and required MSDS. 
- Training. Employee training shall include at least:

- Methods and observations that may be used to detect the presence or release of a hazardous chemical in the work area.

- The physical and health hazards of the chemicals in the work area.

- The measures employees shall take to protect themselves from these hazards, including specific procedures employer has implemented to protect employees from exposure to hazardous chemicals such as appropriate work practices, emergency procedures, and personal protective equipment to be used.

- The details of the Hazard Communication Program developed by the employer, including an explanation of the labeling system and the MSDS and how employees can obtain and use the appropriate hazard information.

Note: Farmworkers in a field where pesticides are being applied or have been applied are not subject to hazard communication training for those pesticides. However, transporters of pesticides are subject to the Hazard Communication Standard training requirements.

Also, workers who may come into contact with other hazardous chemicals in the workplace (such as kerosene or propane) are subject to hazardous communication training for those chemicals.

\section{Inspections and Enforcement}

The same inspection and enforcement criteria apply to OSHA's Hazard Communication Standard as to general OSHA regulations. (See section on General OSHA Regulations.)

\section{Additional Information}

- 29 C.F.R., Part 1910.1200.

- Federal Register, Vol. 52, No. 163, Monday, August 24, 1987, 31851-31886.
- Labor Bulletin No. 453, Florida Fruit and Vegetable Association, Orlando, FL, November $5,1987$.

\section{Responsible Agency}

U.S. Department of Labor

200 Constitution Avenue, NW

Washington, DC 20210

Dial toll-free 1(800) 487-2365

http://www.dol.gov

(See EDIS document FE408, Occupational Safety and Health Act (OSHA) [Federal] for addresses and phone numbers.) 